\title{
DISASTER RISK MONITORING IN RISK MANAGEMENT POLICY
}

\author{
Miroslav Miškić* \\ University of Novi Sad, Faculty for Technical Sciences \\ Goran Ćorić** \\ Singidunum University, Belgrade \\ Danijela Vukosavljević***
}

Union Nikola Tesla University, Faculty of Management, Sremski Karlovci

\begin{abstract}
Climate change has been observed in South East Europe (SEE) through higher temperature, changing precipitation and run-off patterns, and extreme weather, leading to reported increasing incidence of weather-induced disasters in many countries of the region such as floods, droughts, wild fires, strong winds, heat and cold waves, etc. As part of climate change adaptation policies and investments, SEE countries have to focus on reduction of their vulnerability and planning measures to mitigate natural disaster risks. This paper presents the implications of climate change resulting in extreme weather and it analyzes the capabilities of Serbia and its business sector to mitigate and manage the impact of extreme events. The main results of desk and field research carried out in 2016 on disaster risk mitigation are given, as well as emergency preparedness and management and reporting practices in the country, manufacturing, finance and insurance enterprises to reduce the current and future vulnerabilities. The methods used are linear regression and statistical tools. Taking into account the projected impact of climate change for SEE and Serbia by the World Bank's studies, the reduction of the current and future vulnerabilities to climate change risk is very important. Since the aim of this paper is to highlight the importance of investing in risk management knowledge and practices of disaster risk monitoring in risk management policy, the research can contribute to the reduction of the weather-related disaster risks, losses and it can initiate necessary actions for climate change.
\end{abstract}

Key Words: Disaster Risk, Monitoring, Reporting, Risk Management Policy, Finance and Insurance Sector, South East Europe

\section{Introduction}

A broad concept of hazard risk management comprises a systematic process of using administrative decisions, organization, operational skills and capacities to implement policies, strategies, and coping capacities of the society and communities to

\footnotetext{
* Miroslav Miškić, PhD, Assistant Professor at the Faculty for Technical Sciences, University of Novi Sad

** Goran Ćorić, Singidunum University Belgrade, Department for doctoral studies

*** Danijela Vukosavljević, PhD, Assistant Professor at the Faculty of Management, Sremski Karlovci
} 
lessen the impact of natural hazards and the related environmental and technological disasters. Climate change has been observed (World Bank and UN ISDR, 2008) in SEE through higher temperature, changing precipitation and run off patterns, and extreme weather, leading to weather-induced disasters such as floods, droughts, wild fires, strong winds, and heat and cold waves in many countries of the SEE region.

In climate change issues, which increase disaster risk, risk management for a disaster becomes a vital and urgent component of any climate change adaptation program. As part of climate change adaptation policies and investments, SEE countries have to focus on reduction of their vulnerability and planning measures to mitigate natural disaster risks.

The paper reviews the current knowledge on the implications of climate change resulting in extreme weather and it analyzes the capabilities of Serbia as a SEE country to mitigate and manage the impact of extreme events. Therefore, the purpose of this paper in the areas of disaster risk mitigation, emergency preparedness and management practices in public and private sector is to reduce the current and future vulnerabilities.

Strategic dimension of the protection and rescue system in the Republic of Serbia has been established in an integral way by adoption of the National Protection and Rescue Strategy (2011) and it has been normatively regulated by the Law on Emergencies (2009). The starting point in the new system is the principle by which a crisis has to be solved at the place of its occurrence; consequently, a significant part of responsibility has been transferred to local governments. However, it is not followed by necessary legal institutional upgrade of the system, material and technical investment, as well as the appropriate personnel measures. The adoption of the Law has not provoked the expected reaction in the sense of its execution.

The aim of the paper is to contribute to better understanding of disaster risk and its implementation in practice for disaster risk management concerning: vulnerability, hazard characteristics, exposure of persons and assets, capacity and the environment.

Such knowledge can be leveraged for the purpose of:

- Pre-disaster risk assessment, for prevention, mitigation and development;

- Implementation of appropriate preparedness;

- Monitoring and reporting on disaster risk in public and private sector at a national level, and effective response to disasters, and

- Strengthening disaster risk governance, and integration of disaster risk management including business continuity into business models and practices through disasterrisk-informed investments, especially in micro, small and medium-sized enterprises.

\section{Literature overview}

Definitions of mitigation measures are different in the context of disaster risk reduction and climate change, but very often they are defined as human measures to reduce the sources or enhance the sinks of greenhouse gases. Climate change mitigation measures include energy conservation, land use plan enforcement, strengthening institutional and legislative mechanisms, energy efficiency measures, waste management, fossil fuels substitution with renewable energy sources, other measures in the transport and agricultural sectors, and sequestering carbon biologically through reforestation. 
According to the UN International Strategy for Disaster (2006), the term mitigation can be defined as structural and non-structural measures undertaken to limit the adverse impact of natural disasters, environmental degradation and technological hazards. Disaster Risk Management terminology could be presented in the broader framework of adaptation to climate change illustrated by Figure 1.

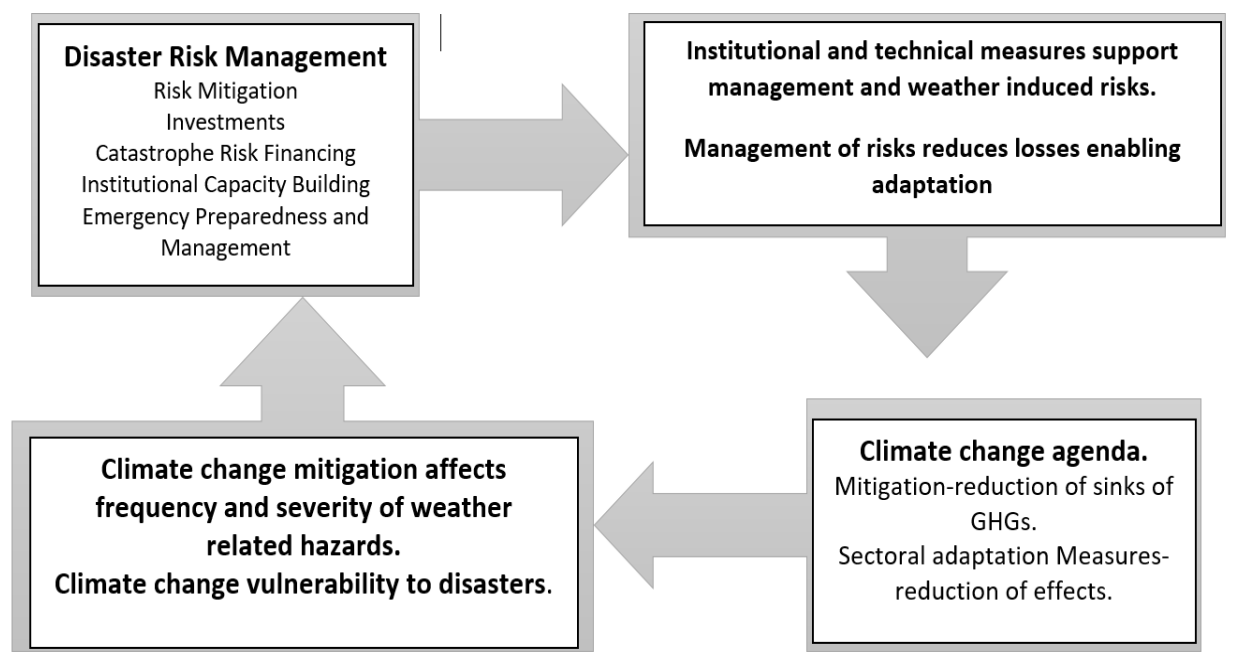

Figure 1 - Climate change and Disaster Risk Management (Source: Pollner et al., 2010)

The capacity of a country to manage risk posed by disasters can be summarized as the concept of hazard risk management institutionalization - the elements of a regulatory framework in place, a sufficiency of the statutory authority to allow for formulation and execution of comprehensive disaster risk programs.

\section{Disaster risk mitigation definition}

According to the World Bank (2005), mitigation means structural and non-structural measures undertaken to limit the adverse impact of natural disasters, environmental degradation and technological hazards. On average, a dollar spent on hazard mitigation saves four dollars in future disasters. Mitigation reduces the impact of disasters, saves lives and reduces economic loss. The measures relevant to be taken for every hazard can be classified as follows:

- Retrofitting. Property protection involves modification of the existing structures to withstand natural hazards. The examples include installing backup valves in sewage and water pipes, elevating structures, installing storm shutters, seismic strengthening, etc.

- Regulations. Regulations involve controlling the use of land and construction of buildings to reduce potential loss. The examples include enforcing building codes and establishing land use zones. 
- Protective Structures. Structures can be built to protect and mitigate the impact of disasters. The examples include erecting sea walls, building safe rooms, and constructing levees.

- Natural Resource Management. Managing natural resources minimizes the risk of hazards. The examples include controlling erosion, managing forests and restoring wetlands.

Mitigation measures can also be grouped into two types of actions as:

- Soft non-structural measures, process-oriented actions completed through the Multi-hazard Mitigation Council, developing the mitigation plan, identifying mitigation actions and implementation strategies, regulations and planning such as mapping hazards and enforcing building codes, and

- Hard measures such as building dykes and reservoirs, usually encompassing structural investments.

The actions to reduce the general risk of natural hazards would include:

- Development of regulatory and institutional framework. A regulatory and institutional framework establishes national responsibilities for risk mitigation by providing the authority to respective governmental agencies to discharge responsibilities related to agreement with government measures. The specific legislation that allows jurisdiction to adopt and enforce land use ordinances and building codes is included in this framework, and

- The framework should also include the development of a national mitigation action plan. After assessing risks and potential mitigation measures, an action plan can be developed describing how actions and investments will be prioritized, implemented and administered.

Hazard monitoring and data collection have the main aim to determine the vulnerability of a country's population with the institutions responsible for monitoring hydrology and meteorology and collecting geological data, which have to be properly equipped.

The development of natural hazard risk assessments for selected areas and hazards, based on the analysis of historical events at these locations, can feed into probability distributions and predictions of likely future occurrences. To undertake a risk assessment, data should be collected and analyzed on the assets and populations exposed in a given location. Probable damage scenarios, vulnerability models and loss scenarios analyses are useful tools, which constitute key foundations for the development of preparedness actions and investments, as well as risk financing options. Hazard risk mapping can provide data on the likelihood and consequences of specific hazards in selected areas of information that gives a basis for risk mitigation prioritization and investments. A critical element in reducing vulnerability could also be an analysis of human settlements and infrastructure in high-risk areas.

Geographic Information Systems (GIS) with layers of digital data can help create risk maps and data sources that enable further use of subsequent mitigation measures such as land-use planning, improved building codes, incorporation into relevant legislation, securing funds for investments.

Furthermore, it is important to develop and implement a public awareness campaign to educate individuals on how they can personally reduce the risk of hazards that occur in their area. Television and radio, schools and community outreach programs can disseminate this kind of information. Public awareness of these risks also helps monitor developments on the ground and keeps authorities accountable for their actions in adaptation and hazard risk mitigation. The hazard risk mitigation and emergency prepared- 
ness project, a multi-hazard public awareness campaign tailored to various target audiences such as children using multiple media including the Internet websites with links to educational tools for students could be developed.

Flood risk reduction. Taking into account the projected impact of climate change and growing risk and losses due to floods in Serbia, flood protection measures to reduce the country's vulnerability have to be improved and expanded, where the following examples of soft and hard measures can be useful:

- Implementation of Flood Management Program to be addressed in river basin and catchment water management plans. Watershed basin planning and feasibility studies for rehabilitation and upgrade of the existing flood protection schemes should be developed or reviewed in light of climate change projections. Flood management also includes flood-plain zoning, development of land use plans and implementation of regulations. Specifically for coastal parts of a country prone to rising water levels in the long term, a flood management program should include coastal planning and development of coastal zone regulations such as shoreline setback requirements.

- Natural Resources Management for restoring resources to their natural state may reduce the impact of flooding. Before all, restoring dunes and beaches can impede coastal erosion. Removal of debris in river channels allows for the natural movement of water and it prevents sediment building up. In order to assist in the design of specific measures, studies for specific watershed areas can be carried out and agreements reached to determine how the management of natural resources within each country can reduce the likelihood of flooding.

- Flood Protection Infrastructure. Flood protection investments that safeguard particular localities may include riverbank protection, improvement of reservoirs and dykes, retrofitting of dams for safety with larger spillways and gates, enlarging floodways, building levees, floodwalls, seawalls/ bulkheads, dam monitoring, reviews and revisions of operating rules for dams, etc. Feasibility studies that incorporate economic, environmental and social assessments should precede decisions on flood protection investments, accounting not only for historical frequency and data loss, but also climate change data and projections as the probability and return periods may change and require a modified technical approach.

- Flood Resistant Construction. A variety of measures can be undertaken to build flood-resistant structures. Firstly, buildings can be constructed with flood-resistant materials, walls can be strengthened to withstand the pressure of floodwaters and floating debris and structures can be properly anchored to foundations or footings. Buildings can be elevated above the average waterline for a 100-year flood event, so that building floors are above floodwater level, and

- Hydro-meteorological Monitoring and Forecasting System. The effective functioning of hydro meteorological systems is very important for disaster preparedness and response. Floods occur not only by inundation of large water plains, but also in small, shallow river areas. Spillage and failure of dams can also cause flooding. In many cases these disasters are predictable in a given time horizon and allow for early warning and response actions, particularly in downstream countries. In order to provide effective warning and response a reliable weather and water monitoring system must be in place. The sharing of meteorological and hydrological data and forecasts is essential both within a country and among upstream and downstream countries. 
Public Awareness Campaigns should develop information on how extreme heat affects the body and what steps to take to reduce the impact of heat, which is important to communicate to save lives. Also, education and public awareness efforts should target specific groups such as farmers, tourists and house owners in vulnerable areas on behavior in the high-risk seasons to reduce wild fire risks (Radović et al., 2013).

Insurance and capital market support. While risk mitigation and adaptation actions are the imperative to reduce losses from events arising with short warning, certain residual risks and losses will materialize, nonetheless. Financial and insurance markets can potentially cover these costs along with creation of special financing and risk transfer facilities in collaboration with the private and public sectors and international institutions (Miškić et al., 2017).

The main concern in the past flood experience was the fact that direct insurers were not buying sufficient coverage at upper layers, presumably because of a combination of short price and career horizons compared to the return periods of the catastrophes concerned. There is some evidence that this is changing, however, possibly driven by the increased frequency of climate change-induced natural disasters in the last decade and a half, where the increased frequency is due to hydro meteorological events and may reflect on cost of catastrophic losses and the impact of human-induced $\mathrm{CO}_{2}$ contamination finally emerging (Miškić et al., 2017).

Aside from balance sheet realities of insurance companies, there are other imperatives for direct insurers to offload climate-induced catastrophe exposures. In particular, it is very uncommon for insurers to be allowed to build reserves for losses that may occur after the current operating cycle. The insurance elements of the new international financial reporting standard do not allow for such reserves, and any catastrophe buffers the need to be held as equity capital. In addition, most tax regimes do not allow catastrophe reserves to be set aside from pre-tax income. Executives or boards are not likely to allow large amounts of unutilized capital to build up in the normal course of events.

The incentive to hold minimal capital will be offset to some extent if current thinking about insurer regulatory capital becomes the norm. This thinking is best captured by the proposed solvency II regime in Europe, which follows the Basel II formulation for banks. Under solvency II, insurers will be required to establish two capital levels, a solvency capital requirement, which represents the economic capital required, given the risk characteristics of the insurer and a minimum capital requirement, below which the insurer will lose their right to trade. If an insurer falls below their solvency capital level, the financial supervisor will be required to intervene in their affairs.

The solvency capital will reflect a range of risks, including market, capital, reserving and underwriting risk. All four of these will be affected by climate change, and the capital allocation for reserving and underwriting risk will include an explicit allowance for retained catastrophe risk. In addition, there is a trend for insurance supervisors to look at the quality of reinsurance when determining insurer solvency.

Smaller countries such as Serbia may require multilateral support (a credit enhancement) to gain access to capital markets. Governments and local industry may simply need to recognize that new mechanisms can both increase coverage and stabilize the cost of premiums. Such assessments require skills in financial modeling, something multilaterals can help organize and finance. 
In the alternative catastrophe bond markets (where the global markets have a capital multiple of approximately 70 times that of the global insurance markets), investors buy high-yield bonds from the party that seeks to be insured. These bonds can either be backed by premiums collected in an underlying insured pool of assets and property or they can be structured as a financial option, where a physical measurable disaster triggers the loss of interest and principal if a major catastrophe occurs during the life of the bond, and thus the bond proceeds are used by the insured party, but lost by the investors. Investors are attracted to these bonds because of their low probability of disaster default while paying attractive yields and their lack of risk correlations with the overall financial markets, which provides them with a diversified asset.

\section{Methods and Materials}

\section{Key research results}

Serbia is a landlocked country situated in Southeastern Europe, in the center of the Balkan Peninsula, between $41^{\circ} 53^{\prime}$ and $46^{\circ} 11^{\prime}$ latitude North and $18^{\circ} 49^{\prime}$ and $23^{\circ} 00^{\prime}$ longitude East on an area of $88,509 \mathrm{~km}^{2}$. The Serbian climate is moderately continental, with localized variations and a gradual change between the seasons. The annual rainfall in low-lying areas ranges from 540 to $820 \mathrm{~mm}$, between 700 and $1000 \mathrm{~mm}$ of rainfall annually in parts of the country $1000 \mathrm{~m}$ above sea-level, while some mountain peaks in Southwestern Serbia have up to $1500 \mathrm{~mm}$ of rainfall a year (Republic Hydro meteorological Service of Serbia, 2012).

The majority of Serbia has continental rainfall patterns with larger volumes in the warmer half of the year, apart from southwestern areas, which have the greatest amount of rainfall in autumn. June is the rainiest month with an average of $12 \%$ to $13 \%$ of the total annual rainfall during this month. February and October are the least rainy months. The normal annual volume of rainfall for the entire country is $896 \mathrm{~mm}$. The northern part of Serbia, Vojvodina, located in the Pannonian Plain, is predominately flat. There are also plains in Mačva, Posavina, Pomoravlje and Stig, as well as in Negotinska Krajina in Eastern Serbia. More than the half of the territory of Serbian land is arable with Vojvodina - the country's main agricultural region. The central part of Serbia and the hilly Sumadija region are located south of the Sava and Danube rivers. Further south, the hills gradually give way to mountains.

Serbia is rich in gorges, canyons and caves, as well as preserved forests, which are home to a multitude of endemic species. Serbian mountains belong to the Rhodopsin range, which runs along the right and left sides of the South and Great Morava rivers and to the Carpathians and Balkan Mountains in the eastern part of the country. Serbia as the country of South East Europe is exposed to a variety of natural hazards including floods, droughts, forest fires, earthquakes and landslides and it is one of the most susceptible countries to floods. On average, Serbia experiences one flood event every two years. 
Disaster Risk Monitoring in Risk Management Policy

Table 1 - Climate change data

\begin{tabular}{|l|l|l|l|l|l|l|l|l|l|l|}
\hline Region & $\begin{array}{l}\text { Mean } \\
\text { Annual } \\
\text { Tem- } \\
\text { perature } \\
\text { Change }\end{array}$ & $\begin{array}{l}\text { Mean } \\
\text { Seasonal } \\
\text { Tempera- } \\
\text { ture } \\
\text { Change }\end{array}$ & $\begin{array}{l}\text { Change } \\
\text { in Mean } \\
\text { Annual } \\
\text { Partici- } \\
\text { pation }\end{array}$ & $\begin{array}{l}\text { Change in } \\
\text { Seasonal } \\
\text { Participa- } \\
\text { tion }\end{array}$ & $\begin{array}{l}\text { Change } \\
\text { in An- } \\
\text { nual } \\
\text { Runoff }\end{array}$ & $\begin{array}{l}\text { Participa- } \\
\text { tion } \\
\text { Intensity }\end{array}$ & $\begin{array}{l}\text { Participa- } \\
\text { tion } \\
\text { Per } \\
\text { Extreme } \\
\text { Events }\end{array}$ & $\begin{array}{l}\text { Con- } \\
\text { secutive } \\
\text { Dry Days }\end{array}$ & $\begin{array}{l}\text { Frost } \\
\text { days }\end{array}$ & $\begin{array}{l}\text { Heat } \\
\text { Wave } \\
\text { duration }\end{array}$ \\
\hline SEE & & $\begin{array}{l}2.1^{\circ} \mathrm{C} \\
\text { (Summer) }\end{array}$ & & - -(Summer) & & & & & & \\
\hline Europe & $1.8^{0} \mathrm{C}$ & $\begin{array}{l}1.0^{0} \mathrm{C} \\
\text { (Winter) }\end{array}$ & $-6 \%$ & $\begin{array}{l}-6 \%(\text { Win- } \\
\text { ter) }\end{array}$ & $-25 \%$ & $2 \%$ & - & 5 & -17 & 23 \\
\hline
\end{tabular}

(Source: UN, 2008)

In most cases, occurrence, scope and duration of natural disasters cannot be predicted in advance, but there are some phenomena for which, based on experience, statistics and methods of modeling, as well as the place where they usually occur, it is possible to expect that they could occur. An assessment of vulnerability of the territory of the Republic of Serbia to floods and landslides has been done and on the basis of the available statistics the map of natural disasters risk (forest fires, floods, landslides and earthquakes) has been made. Table 2 shows the estimated area of the Republic of Serbia vulnerable to natural hazards and it covers the total area of $57.33 \%$ (Dragićević et al., 2011).

Table 2 - Areas vulnerable to natural hazards in the territory of Serbia

\begin{tabular}{|l|l|l|}
\hline Natural hazard & $\begin{array}{l}\text { Area } \\
\left(\mathrm{km}^{2}\right)\end{array}$ & $\begin{array}{l}\text { Percentage of total Ser- } \\
\text { bian area (\%) }\end{array}$ \\
\hline Seismic hazard VI II-IX MCS & 16388.59 & 18.55 \\
\hline Seismic hazard IX-X MCS & 1109.71 & 1.26 \\
\hline Excessive erosion areas & 3320.80 & 3.76 \\
\hline Landslide hazard areas & 13327.60 & 15.08 \\
\hline Areas vulnerable to drought & 18306.93 & 20.72 \\
\hline Potential floodable areas & 15198.07 & 17.20 \\
\hline Highest risk of forest fires & 3154.95 & 3.57 \\
\hline Vulnerable areas in Serbia & 50659.87 & 57.33 \\
\hline
\end{tabular}

(Source: The World Bank, 2016)

Most experts agree that climate changes will cause more frequent extreme climate consequences such as floods, landslides and fires (Sekulić, et al., 2012). The positive trend of number of catastrophic and unfavorable natural events especially reflects in the events depending on meteorological conditions. Table 3 contains the data related to the natural disasters registered in the last 20 years on the territory of Serbia. 
Table 3 - Extreme events in Serbia, 1980-2017

\begin{tabular}{|c|c|c|c|c|c|c|}
\hline Process type & Date & $\begin{array}{l}\text { Catchment } \\
\text { area/Region }\end{array}$ & Municipality & Fatalities & $\begin{array}{l}\text { Overall } \\
\text { losses }(€)\end{array}$ & $\begin{array}{l}\text { Additional } \\
\text { information }\end{array}$ \\
\hline \multirow[t]{3}{*}{ Earthquake } & May 1980 & Kopaonik & & & & $\begin{array}{l}\text { Measuring } 5,8 \\
\text { on Richter } \\
\text { scale }\end{array}$ \\
\hline & $\begin{array}{l}\text { September } \\
1998\end{array}$ & & Mionica & & & $\begin{array}{l}\text { Measuring } 5,7 \\
\text { on Richter } \\
\text { scale }\end{array}$ \\
\hline & $\begin{array}{l}\text { November } \\
2010\end{array}$ & & Kraljevo & $\begin{array}{l}2 \text { killed, } \\
180 \text { in- } \\
\text { jured }\end{array}$ & & $\begin{array}{l}\text { Measuring } 5,4 \\
\text { on Richter } \\
\text { scale }\end{array}$ \\
\hline \multirow[t]{2}{*}{ Flood } & 1999 & $\begin{array}{l}\text { The river } \\
\text { Velika Mo- } \\
\text { rava }\end{array}$ & Šumadija & 8 & & $\begin{array}{l}30 \text { bridges } \\
\text { damaged }\end{array}$ \\
\hline & 2005 & $\begin{array}{l}\text { The river } \\
\text { Tamiš }\end{array}$ & $\begin{array}{l}\text { Sečanj, } \\
\text { Žitište, } \\
\text { Plandište }\end{array}$ & & & $\begin{array}{l}85,000 \text { people, } \\
150 \text { houses } \\
\text { flooded, } 1,000 \\
\text { people evacu- } \\
\text { ated }\end{array}$ \\
\hline \multirow[t]{5}{*}{$\begin{array}{l}\text { Landslides } \\
\text { and escarp- } \\
\text { ments }\end{array}$} & 2014 & Serbia & $\begin{array}{l}24 \text { munici- } \\
\text { palities }\end{array}$ & 51 & $1,800,000,000$ & $\begin{array}{l}31,879 \text { people } \\
\text { evacuated }\end{array}$ \\
\hline & 2006 & Bogdanje & Trstenik & & & $\begin{array}{l}130 \text { houses } \\
\text { destroyed }\end{array}$ \\
\hline & 2014 & $\begin{array}{l}\text { Umka- } \\
\text { Duboko }\end{array}$ & Belgrade & Belgrade & $54,000,000$ & $\begin{array}{l}\text { Area of } 1.8 \\
\mathrm{~km}^{2}, \text { about } \\
14,000,000 \mathrm{~m}^{3}\end{array}$ \\
\hline & 2014 & Krupanj & Krupanj & & $4,680,000$ & $\begin{array}{l}389 \text { facilities } \\
\text { either dam- } \\
\text { aged or de- } \\
\text { stroyed }\end{array}$ \\
\hline & 2014 & Kladovo & Kladovo & & & 30 landslides \\
\hline \multirow[t]{2}{*}{$\begin{array}{l}\text { Blizzards and } \\
\text { snowdrifts }\end{array}$} & $\begin{array}{l}\text { February } \\
2014\end{array}$ & $\begin{array}{l}\text { Vojvodina, } \\
\text { Eastern } \\
\text { Serbia }\end{array}$ & $\begin{array}{l}\text { Feketić, } \\
\text { Majdanpek, } \\
\text { Knjaževac }\end{array}$ & & & $\begin{array}{l}5 \mathrm{~m} \text { high } \\
\text { snowdrifts }\end{array}$ \\
\hline & $\begin{array}{l}\text { January } \\
2017\end{array}$ & & $\begin{array}{l}13 \text { munici- } \\
\text { palities in } \\
\text { Serbia }\end{array}$ & $\begin{array}{l}\text { Several } \\
\text { people }\end{array}$ & $\begin{array}{l}60,000 \text { per } \\
\text { day }\end{array}$ & $\begin{array}{l}\text { Regular ice } \\
\text { defense along } \\
\text { part of the } \\
\text { Danube, Sava } \\
\text { and the entire } \\
\text { flow of the Tisa }\end{array}$ \\
\hline \multirow[t]{2}{*}{ Hail } & May 2015 & $\begin{array}{l}\text { Central } \\
\text { Serbia }\end{array}$ & $\begin{array}{l}\text { Arilje, Kragu- } \\
\text { jevac }\end{array}$ & & $10,000,000$ & $\begin{array}{l}50 \% \text { of rasp- } \\
\text { berry growing } \\
\text { areas }\end{array}$ \\
\hline & June 2016 & Banat & Pančevo & & & $\begin{array}{l}\text { Damaged } \\
\text { facilities, } \\
\text { vehicles, } \\
\text { crops }\end{array}$ \\
\hline
\end{tabular}


Disaster Risk Monitoring in Risk Management Policy

\begin{tabular}{|c|c|c|c|c|c|c|}
\hline Process type & Date & $\begin{array}{l}\text { Catchment } \\
\text { area/Region }\end{array}$ & Municipality & Fatalities & $\begin{array}{l}\text { Overall } \\
\text { losses }(€)\end{array}$ & $\begin{array}{l}\text { Additional } \\
\text { information }\end{array}$ \\
\hline \multirow[t]{8}{*}{ Drought } & 2000 & $\begin{array}{l}\text { Vojvodina } \\
\text { and Central } \\
\text { Serbia }\end{array}$ & & & $657,000,000$ & $\begin{array}{l}\text { Extreme } \\
\text { drought, 37-61 } \\
\text { tropic days }\end{array}$ \\
\hline & 2003 & $\begin{array}{l}\text { Vojvodina } \\
\text { and Central } \\
\text { Serbia }\end{array}$ & & & $940,000,000$ & $\begin{array}{l}\text { Extreme } \\
\text { drought } 2007\end{array}$ \\
\hline & 2007 & Serbia & & & $564,000,000$ & $\begin{array}{l}\text { Caused } 258 \\
\text { forest fires }\end{array}$ \\
\hline & 2011 & $\begin{array}{l}\text { Eastern, } \\
\text { Southeast- } \\
\text { ern and } \\
\text { Central } \\
\text { Serbia }\end{array}$ & & & $470,000,000$ & $\begin{array}{l}\text { Extreme } \\
\text { drought }\end{array}$ \\
\hline & 2012 & $\begin{array}{l}\text { Vojvodina } \\
\text { and Central } \\
\text { Serbia }\end{array}$ & & & $1,900,000,000$ & $\begin{array}{l}5 \text { to } 8 \text { heat } \\
\text { waves }\end{array}$ \\
\hline & $\begin{array}{l}\text { March } \\
1914-1918\end{array}$ & Serbia & & $\begin{array}{l}150,000- \\
200,000\end{array}$ & & Typhus \\
\hline & March 1972 & $\begin{array}{l}\text { Serbia - total } \\
\text { number of } \\
174 \text { persons }\end{array}$ & $\begin{array}{l}1 \text { in Vo- } \\
\text { jvodina }\end{array}$ & $\begin{array}{l}175 \text { ill, } 35 \\
\text { dead }\end{array}$ & & Variola \\
\hline & $\begin{array}{l}1998, \\
2010, \\
2014\end{array}$ & $\begin{array}{l}\text { Sokobanja, } \\
\text { Pčinja, } \\
\text { Gadžin Han }\end{array}$ & & $\begin{array}{l}- \\
16 \\
30\end{array}$ & & $\begin{array}{l}\text { 1998, 2010, } \\
2014 \\
\text { Tularemia }\end{array}$ \\
\hline
\end{tabular}

(Source: Seismological survey of Serbia, 2012; The World Bank, 2016)

According to the Institute of Agricultural Economics in Belgrade, the damage caused by the drought in 2012 was more than 2 billion dollars, and in 2011 about 500 million dollars (Dželetović et al., 2013).

As the result of floods in 2014, the total number of 1.6 million people in the whole country were either directly or indirectly affected by the disaster. Floods and landslides caused death of 51 people out of which 23 people drowned. Besides this, another 31,879 persons were temporarily evacuated from their flooded and destroyed homes; 24,000 of them were from Obrenovac. Most of the evacuated persons found their shelter with their relatives, but 5,000 were placed in temporary accommodation organized by the Red Cross of Serbia and the Serbian Government. This doubled the number of internally displaced people, which had made the majority of the displaced people even before the floods. The total value of the destroyed goods in 24 affected municipalities covered by damage assessment was 885 million Euros, and the value of the losses was 640 million Euros, so the total amount was 1,525 million Euros as shown in Table 8. This amount of money makes $3 \%$ of total gross domestic product in the whole country providing evidence of seriousness of the catastrophe caused by the floods and landslides. The damage from the flood in Kolubara mines is estimated to minimum 100 million Euros. Water turned Kolubara mines into lakes. Each of the four mines was flooded, two of them completely. In the biggest OPM Tamnava - West Field even 10 excavators were flooded and six of them were completely under water. Min- 
ing Basin Kolubara produces $70 \%$ of Serbian lignite, which is used in thermal power plants TENT producing more than $50 \%$ of Serbian electricity. At some places, water is as deep as 60 meters. In Obrenovac and the region, 22 power transformer stations were flooded and one cannot enter there. When some municipalities, which were not included in the needs assessment in the process of renovation and which were affected by the disaster less than previously mentioned ones, have been taken in consideration, the estimated value of the damages and losses should be increased from 1.7 to 1.8 million Euros (Government of the Republic of Serbia et al., 2014).

The World Bank (2005) identified the weather dependent economic sectors in the Republic of Serbia, participation of these sectors in gross national income (without VAT), registered and assessed damage. Participation of the weather dependent sectors in gross national income of the Republic of Serbia (without the autonomous Province Kosovo and Metohija), for the period from 2000 to 2004 varied from 42\% to 43.8\%. In 2005 participation of the weather dependent sectors in gross national income of the Republic of Serbia was already $47.18 \%$. The World Bank Study comprised only $49 \%$ of the weather dependent sectors, and it did not take the damage caused by forest fires into consideration. However, 258 forest fires were registered during 2007. The area of 33.000 hectares of overgrowth was burnt and out of that area 16.000 hectares were forest area. The forest fires caused the damage of about 40 million Euros. 24 million Euros was the amount necessary only for recovery. Indirect damage was not estimated.

Table 4 shows the estimated damage in the weather dependent sectors in the Republic of Serbia. There is no doubt that Serbian economy suffers enormous losses in material goods, but it is also obvious that the atmospheric disasters on the territory of the Republic of Serbia cause losses in human lives.

Table 4 - Estimated damage in the weather dependent sectors in the Republic of Serbia

\begin{tabular}{|c|c|c|}
\hline \multirow{2}{*}{$\begin{array}{l}\text { Sector/unfavorable weather } \\
\text { events }\end{array}$} & \multicolumn{2}{|c|}{ Estimation of losses in sectors } \\
\hline & $\begin{array}{l}\text { Average annual losses in } \\
\text { millions of dinars }\end{array}$ & $\begin{array}{l}\text { Average annual losses in } \\
\text { human lives }\end{array}$ \\
\hline Agriculture/floods & from 3.100 to 8.500 & Several to tenths \\
\hline Waterpower engineering/floods & About 1.960 & - \\
\hline $\begin{array}{l}\text { Agriculture/hail, heavy rainfalls, } \\
\text { strong wind }\end{array}$ & About 7.316 & $\begin{array}{l}\text { Several to tenths killed by } \\
\text { thunder stroke }\end{array}$ \\
\hline Agriculture/ drought, frost & About 4.000 & No losses \\
\hline $\begin{array}{l}\text { Production of energy (heat)/ } \\
\text { extremely low air temperature }\end{array}$ & About 716 & Several to tenths \\
\hline $\begin{array}{l}\text { Maintenance of roads/snow, ice, } \\
\text { icing }\end{array}$ & About 3.500 & \\
\hline \multicolumn{3}{|c|}{$\begin{array}{l}\text { Losses in human lives on highways, regional and local roads caused by bad weather } \\
\text { conditions vary from } 105 \text { to } 131 \text { per year }\end{array}$} \\
\hline Commercial air traffic & From 54 to 72 & \\
\hline TOTAL & From 16.648 to 48.572 & From several to 160 \\
\hline
\end{tabular}

(Source: The World Bank, 2016) 
Reporting, awareness and knowledge has been assessed as highly important for the implementation of climate change policy as these activities could strengthen national expertise in different areas: increase in public awareness on various issues; provision of information that is necessary to formulate national policies and measures in the area and informing donors about the achievements and needs of countries. Monitoring and Reporting is necessary for the further implementation of domestic mitigation measures and it is necessary for obtaining international support for NAMAs. This requires detailed quantitative and qualitative evidence. Thus, a monitoring and reporting system should be in place in the country in public and private sector, too.

The monitoring and reporting and improvement of the capacity to establish an efficient Measurement, Reporting and Verification (MRV) system could be assessed as not sufficient in Serbia. Although monitoring and evaluation of implementation of climate change policies is considered important, the existing system for GHG inventory is evaluated as insufficient together with the monitoring system for the implementation of the national climate change policy. According to the institutional point of view, the climate change departments exist in the following Serbian ministries: environment (climate change division, 5 employees), energy (Department for Sustainable Development and Climate Change) and foreign affairs. Additionally, there are climate change experts in environment, economy/finance, agriculture/forestry, energy, transportation, health, foreign affairs and other organizations/institutions - between 1 and 2. At the national level in Serbia there are the Initial National Communication; the National Strategy for incorporation of the Republic of Serbia into Clean Development Mechanism under the Kyoto Protocol for waste management, agriculture and forestry sectors; the National Environmental Protection Programme; the National Sustainable Development Strategy (NSDS) and Action Plan for the implementation; the Serbian Energy Development Strategy by 2015; the Forestry Development Strategy; the Strategy for Scientific and Technological Development; the National Strategy for Biodiversity.

As the Western Balkan country the accession to the EU presents for Serbia a challenge to meet the relevant climate change requirements, but at the same time it is an opportunity in terms of financing sources. However, there is a need of a certain level of capacity in order to have an access to the existing financing and to prepare for the future financial assistance.

Although Serbia had an open access to the EU funds: IPA, TAIEX, UNFCCC: GEF, bilateral donors: the Government of Japan - Capacity Development project on National Appropriate Mitigation Actions; the Government of Norway - development of National Strategy for incorporation of the Republic of Serbia into Clean Development Mechanism under the Kyoto Protocol; the Government of Spain - Feasibility Study "Efficient ways for GHG emissions reduction under the post-Kyoto framework"; the Government of Italy, different activities related to climate change have showed that there is a need for more capacity building in order to be able to use the EU funds efficiently and that the EU funds are not sufficient to meet the country's needs in the area of climate change. There are certain activities related to capacity building of Serbia of all relevant stakeholders including representatives of energy and industry sector, in order to introduce those key elements of EUETS and to prepare them for the future implementation. 
The established practices for risk management are very important, but not regulated enough as a set of obligations of organizations of protection against natural and other bigger disasters and creation of the conditions for their elimination, i.e. reduction of their consequences because of what presented are also the results of the qualitative research in private sector concerning the disaster risk management reporting practices. Some results of the research carried out in business sector on reporting on disaster risk are presented further in this paper.

\section{Risk management monitoring and reporting on disaster risks practices of manufacturing, financial and insurance companies}

In 2016 the field research was conducted in Serbia in 100 manufacturing enterprises, financial and insurance companies on varios disaster risk management issues, assessment and monitoring practices. For the purpose of this paper those concerning practices in risk management reporting on disaster risks are presented.

The Hypotesis was: The reporting on disaster risk management has the important impact on enterprise income. The basic descriptive methods of statistical analysis and linear regression were used for the analysis. The impact of the further three dichotomus variables is presented:

$\mathrm{X}_{1}=$ Risk of the lack of internal reporting on disaster risk,

$\mathrm{X}_{2}=$ Risk of the lack of internal reporting on disaster risk determined by the auditor,

$\mathrm{X}_{3}=$ Risk of the lack of internal reporting on disaster risk established by the competent institution.

According to the research results, the highest impact of disaster risk reporting and monitoring on the enterprises revenue and income had variable $X_{1}$ (30\% of respondents).

Variable $\mathrm{X}_{2}$ (less than one quarter of respondents) confirmed that the impact of Lack of internal reporting on disaster risk determined by the auditor had been of importance for the revenue.

Some (over $10 \%$ of respondents) think that Risk of the lack of internal reporting on disaster risk established by the competent institution is of importance for the revenue of the enterprise. Table 5 shows the values of regression coefficients and standard errors.

Table 5 - Achieved values of logistic regression

\begin{tabular}{lllll}
\hline Variables & OR & $\begin{array}{l}\text { Regression } \\
\text { coefficients }\end{array}$ & Standard error \\
\hline Regression constant & & 0.4853 & $3.62 \mathrm{E}-02$ \\
$X_{1}$ & $\begin{array}{l}\text { lack of internal reporting } \\
\text { on disaster risk }\end{array}$ & 0.4125 & 0.0253 & $5.29 \mathrm{E}-02$ \\
$X_{2}$ & $\begin{array}{l}\text { lack of internal reporting } \\
\text { on disaster risk determi- } \\
\text { ned by the auditor } \\
\text { lack of internal reporting } \\
\text { on disaster risk establis- } \\
\text { hed by the competent } \\
\text { institution }\end{array}$ & 0.3140 & 0.0094 & $6.79 \mathrm{E}-02$ \\
\hline
\end{tabular}


Disaster Risk Monitoring in Risk Management Policy

\begin{tabular}{|c|c|c|c|c|}
\hline Variables & & OR & $\begin{array}{l}\text { Regression } \\
\text { coefficients }\end{array}$ & Standard error \\
\hline $\begin{array}{l}\text { Total assessment error } \\
\text { (Q): }\end{array}$ & 0.2724 & & & \\
\hline $\begin{array}{l}\text { Determination } \\
\text { coefficient }\left(R^{2}\right) \text { : }\end{array}$ & 0.8091 & & & \\
\hline AlC: & 32.739 & & & \\
\hline
\end{tabular}

(Source: Authors)

All estimated regression coefficients have positive values, confirming the validity of the Hypothesis. The estimated values show the impact of all dichotomous variables (i.e. the type of risk of financial reporting on climate risk) on achieved income (and business as a whole) in the surveyed legal entities, emphasizing the lack of internal reporting on this risk as the most important one.

\section{Discussion and Conclusions}

The issues on disaster risk monitoring in the risk management policy in Serbia have been presented in this paper.

The main goal of the illustrated data in the paper was to better understand capacity issues that Serbia faces in response to the new challenges of climate change, in particular related to formulating comprehensive approach to ensure sustainable human development using emerging opportunities. Besides the literature overview, the paper discusses the projected impact of climate change, the reduction of the current and future vulnerabilities to hydro meteorological risk that should be built on and how to expand the existing disaster risk management efforts. The disaster mitigation could be more successfully assessed if it is based on the past vulnerabilities may not sufficient in light of recent scientific forecasts, which leads us to the conclusion that the existing mechanisms in Serbia are already insufficient for the current level of vulnerabilities.

Coordination mechanisms among the EU are not well developed, concerning both the horizontal coordination among various sectors and the linkages between the central and local levels.

Hazard warning and monitoring systems require improvement. The country's hydro meteorological systems, in particular, should be enhanced, and technological advancements in this area should be integrated. Hydro meteorological data can be a very efficient tool for collaboration and information sharing.

Economic considerations are not fully integrated in investment decisions. It is important that cost-benefit or cost-efficiency analysis is part of the investment prioritization process necessary for the development of sectoral, national and local disaster risk mitigation plans and climate change adaptation strategies.

Catastrophe risk financing tools are not fully utilized. Insufficient funding of disaster risk mitigation investments further underlines the question of capacity building of Serbia to apply successfully for the open EU funds.

While the importance of mitigating the risk of natural hazards is recognized in Serbia, it still does not have a comprehensive disaster risk reduction strategy and a multi-year cross-sectoral 
investment plan. Also, at the level of business sector a comprehensive disaster risk planning and reporting system is necessary, as internal and controlled mechanisms from external auditors for the reduction of possible impact on the revenues and income of the enterprises.

\section{References}

[1] Dragicevic, S., Ristic, R., Zivkovic, N., Kostadinov, S., Tosic, R., Novkovic, I., Borisavljevic, A., Radic, B. (2013). Floods in Serbia in 2010 - Case Study: The Kolubara and Pcinja River Basins. Geomorphological impacts of extreme weather, Springer Geography, 155-169.

[2] Dragicevic, S., Filipovic, D., Kostadinov, S., Ristic, R., Novkovic, I., Zivkovic, N., Andjelkovic, G., Abolmasov, B., Secerov, V., Djurdjic, S. (2011).Natural Hazard Assessment for Land-use Planning in Serbia, International Journal of Environmental Research, Vol.5, No.2, pp. 371-380.

[3] Dzeletovic, M., Knezic, T., Cvetkov, M. (2013) . Economic implications of natural disasters with special emphasis on the situation in Serbia, Ecologica, No. 70, pg.118.

[4] Government of the Republic of Serbia, European Union, United Nations and World Bank. (2014). Floods in Serbia in 2014: Report on assessment of the needs for recovery and renovation after the damages caused by floods. Belgrade. 2014.

[5] National Strategy for Protection and Rescue in Emergencies. (2011). "RS Official Gazette", $\mathrm{N}^{0} 86 / 2011$

[6] Miskic, M., Coric, G., Beslac, M. (2017).Banking and Insurance Risk Management of Floods, Ecologica, Vol. 24, No.88

[7] Miskic, M., Coric, G., Vukosavljevic, D. (2017).Building Financial and Insurance Resilience in the Context of Climate Change, Ekonomikapoljoprivrede, No.3/2017, str.121

[8] Pollner, J., Kryspin-Watson, J., Nieuwejaar, S. (2010). Disaster Risk Management and Climate Change Adaptation in Europe and Central Asia, World Bank.

[9] Radović-Marković, M., Grozdanić, R., Jovancević, D., Jevtić, B., Vukosavljević, D. (2013) .The Importance of the Environment Vulnerability Monitoring,International Scientific Conference on Impact of Climate Change on the Environment and the Economy, Belgrade, 22-24.April 2013, Book of Abstracts,pg. 39,ISBN 978-86-89061-03-1, COBISS.SR-ID 197921036.

[10] Republic Hydro meteorological Service of Serbia. (2012). Climatological Analysis of the Year 2012 for the Territory of the Republic of Serbia, Belgrade.

[11] Sekulic, G., Dimovic, D., Kalmar KrnjajskiJovic, Z., Todorovic, N. (2012). Estimation of vulnerability to climate changes: Serbia Belgrade: Centre for the Environment Improvement: The World Fund for Nature, 2012, Novi Sad: Stojkov, pg. 66.

[12] Seismological survey of Serbia (2012).Map of epicenter of the earthquakes in Serbia in the period 1456-2012 www.seismo.gov.rsAccessed in Oct. 2017

[13] The Law on Emergencies. (2009). "RS Official Gazette", № 111/2009, 92/2011 and 93/2012

[14] The World Bank and UN ISDR. (2008). Mitigating Adverse Financial Effects of Natural Hazards on the Economies of South Eastern Europe. World Bank.

[15] The World Bank. (2005). Basic Terms of Disaster Risk Reduction. Disaster risk management working paper series, No. 9, World Bank.

[16] The World Bank (2016). Development of master curricula for natural disasters risk management in Western Balkan countries, WB Project (573806-EPP-1-2016-1-RS-EPPKA2-CBHE-JP).

[17] UN International Strategy for Disaster (2006). A Glance at Key climate change and Disaster risk reduction concepts, United Nations.

[18] The World Bank. (2005). Study on Economic Benefits of RHMS of Serbia. Belgrade. Serbia.

[19] UN. (2008). South Eastern Europe Disaster Risk Reduction and Adaptation Initiative Risk Assessment for South Eastern Europe, Desk Study Review, Geneva. 